\title{
Why Did Stalin Not Support a Quick Victory for the Korean People's Army? Stalin's Unspoken Global Security Strategy for the Korean War
}

\author{
Youngjun Kim
}

In this paper, I argue that Stalin maintained a maximum gain/minimum risk security strategy during the Korean War. For the first time, I challenge a common misconception that the Korean People's Army of North Korea copied and followed the Soviet Army's operational strategy during the war. I question why the KPA did not follow the Soviet Army's operational concept in guranteeing a quick victory, and why the Kremlin and Soviet military advisors kept silent during the initial stage of the war. Because the KPA did not follow the Soviet Army's operational strategy initially, the United Nations forces were able to arrive in Pusan, extending the war. Why didn't Stalin want a quick victory? Did Stalin want bigger benefits than a quick victory on the Korean Peninsula by delaying the war and distracting the enemy? By examining the KPA's performance according to the Soviet Army's operational concept, I argue that Stalin wanted to use the Korean War as a useful card in his global struggle against the United States. He wanted to lower the risk of war in the European theater because Europe was more strategically significant than Northeast Asia. The memory of Nazi Germany's invasion was still fresh in Stalin's mind at the outbreak of the Korean War. Throughout the war, Stalin's top priority was the national interests of the Soviet Union, and he did not take into account the costs to allies China and North Korea.

Key Words: Stalin, Korean War, Korean People's Army, Cold War, Soviet Union

*Youngjun Kim (bumanbake@hotmail.com) is a professor of national security affairs in the National Security College at Korea National Defense University. His book Origins of the North Korean Garrison State: People's Army and the Korean War was published by Routledge in 2017. He received a doctorate in the history of international politics at the University of Kansas and a MSc in public policy at King's College, London. He is a Senior International Research Fellow of the U.S. Department of Defense's Think Tank, Foreign Military Studies Office (FMSO), an official member of the ROK-U.S. Combined Forces Command Commanders' Strategic Shaping Board (CSSB), and a policy advisor on securitiy, defense and military issues for the ROK President's Office (the Blue House), National Security Council, National Assembly, Ministry of Foreign Affairs, Ministry of National Defense, Department of Unification, and the Joint Chiefs of Staff. 
I $\mathrm{n}$ this paper, I argue that Stalin pursued a maximum gain/minimum risk security strategy during the Korean War. For the first time, I challenge the commonly accepted academic opinion that the Korean People's Army of North Korea copied and followed the Soviet Army's operational strategy during the war. I question why the KPA did not follow the Soviet Army's operational concept in guaranteeing a quick victory, and why the Kremlin and Soviet military advisors kept silent during the initial stage of the war. Because the KPA did not follow the Soviet Army's operational strategy during the initial period of the war, the United Nation forces were able to arrive at Pusan, extending the war. Why did Stalin not want a quick victory? Did Stalin want bigger benefits than a quick victory on the small Korean Peninsula by delaying the war and luring the enemy into a protracted, and costly, conflict? By examining the KPA's performance according to the Soviet Army's operational concept that Soviet military advisors at the time of the Korean War had mastered during the Second World War, I want to strengthen the argument that Stalin wanted to use the Korean War as a useful card in his global struggle against the United States. He wanted to lower the risk of war in the European theater because it was more strategically significant than the Far East, partly because of the memory of Hitler's invasion of the Soviet Union just a few years earlier. Stalin had multiple objectives in the war, not just the creation of a small security buffer zone. Due to his decision to not contribute troops to Kim Il Sung's war effort, Stalin did not sacrifice Soviet lives during the Korean War; rather, he depended on his junior partners, the North Koreans and Chinese. The North Koreans and Chinese ultimately paid the price for enhanced Soviet security although a small number of Soviet advisors and pilots directly participated in the war. Before the war, an inexperienced Kim Il Sung believed in his plan for a quick victory and expected some direct support from the Soviet Union, although Stalin clearly told Kim before the war that the Soviet Union would not intervene directly. For Kim Il Sung, this war was a total war; however, for Stalin, it was a limited war that would tie down the Americans and diminish the risk of another world war in Europe. Stalin was neither a risk-taker nor an idealist who supported Third World revolutions. Stalin, a Machiavellian by nature, wanted to use the Korean War to prevent a major conflict with the United States and saw American intervention in the Korean War, and direct U.S.-China military conflict, as directly benefitting longterm Soviet security. According to Stalin's calculation, the Soviet Union would benefit from this small internationalized civil war whether or not Kim Il Sung won the war. The Korean War allowed Stalin and the Soviet Union to recover from the devastation of the Second World War and avoid another major conflict in Europe. Before the Korean War, the Soviet Union was uncertain whether the 
United States would intervene; however, it was clear that Stalin changed his strategy according to changes in the situation of the Korean War. Throughout the war, it was obvious that Stalin's top priority was the national interests of the Soviet Union, and he did not take into account the costs to its alliance partners of the People's Republic of China and North Korea.

Recently, some historians, including Kim Donggil (2011) of Beijing University, have similarly argued that Stalin manipulated the Korean War in the interests of the Soviet Union and Eastern Europe. ${ }^{1}$ However, these historians have not considered the military aspects of the Korean People's Army's operational strategy during the Korean War. Instead, these historians have focused more on the diplomatic aspects of the relations of participating countries. In this paper, I question why the KPA missed an opportunity to unify Korea during the initial stage of the war, and why Soviet advisors designed an invasion plan for the KPA that did not follow the Soviet style of warfare. I analyze the operational style of the KPA, particularly during the initial stage of the war, within the Soviet's Army's operational strategy that Soviet miliary advisors followed hundred times during World War II just a few years previously. In past studies, there have been no questions asked about whether the KPA conducted Soviet-style operations during the Korean War because the KPA's organization, weapons, training, and invasion plan were designed and implemented by the Soviet military. Indeed, Soviet advisors and Soviet-Koreans supported and helped in the creation of the KPA, and the organizational structure of the KPA copied the Soviet Army's. However, regarding the KPA's performance during the war, I argue that the KPA did not conduct Soviet-style operations during the initial stage of the war in guaranteeing a quick victory and stopping the arrival of UN forces. Because of this, the KPA missed a golden opportunity to unify Korea and stop the arrival of the UN troops. More importantly, Soviet military advisors, who had mastered Soviet-style operations used against Nazi Germany during the Second World War and knew how to win a quick victory, did not design an invasion plan for the KPA for a quick victory. Furthermore, Stalin did not advise the KPA to follow the Soviet style of war to win as quickly as possible. Not surprising, there is no written documents explaining why Soviet advisors neither planned nor advised the KPA based on their expertise and experience in the Soviet style of war. Clearly, the KPA did not follow the Soviet's 'Deep Operation' strategy to conclude the war more quickly and successfully. From this, I can suggest a hypothesis that it

\footnotetext{
${ }^{1}$ Professor Kim argued that Stalin decided to support the Korean War during Sino-Soviet negotiations because Stalin wanted to strengthen socialism in Europe by drawing U.S. attention to Asia due to China's intervention in the Korean War.
} 
would be possible that the Kremlin and Soviet military advisors did not want a quick victory for the KPA to unify Korea; rather, Stalin maintained a wait-andsee strategy on the UN intervention to delay the war and to lure the enemy into a protracted conflict. Another hypothesis offered here is that, because the KPA's initial target of invasion was to occupy Seoul as a limited war, and not fight a total war to occupy whole peninsula, Soviet advisors did not need to plan the KPA's invasion based on the Soviet style of war to support a quick victory of a total war. Nonetheless, when the war began and the United States decided to intervene in the war during a meeting of the UN Security Council, the Kremlin and Soviet military advisors naturally had to advise the KPA to maximize its speed to stop an arrival of the UN forces to achieve a quick victory. In this paper, I explain the Soviet style of operations that Soviet advisors mastered during World War II and show how the KPA's performance was in opposition to that Soviet operational concept. This is a new argument differing from past studies on the Korean War and a new challenge to the belief that the KPA copied and followed the Soviet style of operations based on tank units and their maximum speed.

I examine Stalin's vision of the war in Korea at three stages. First, Stalin had maintained his skeptical view of Kim Il Sung's plan for invasion up until January 1950. Second, Stalin suddenly changed his view of Kim's plan during negotiation of the Sino-Soviet Friendship Treaty in January 1950. Before the Americans intervened in the Korean War, Stalin supported Kim's vision to achieved a quick victory via a massive uprising of the Korean communists in South Korea (Weathersby 1993; 1995a; 1995b; 1998; 2002; 2003). Third, after the U.S. intervention, Stalin saw the Korean War as an opportunity to weaken the United States by support a proxy war fought by the KPA and Chinese Volunteer Forces (CVF), not Soviet troops. Throughout the armistice talks, Stalin wanted to delay the war as long as possible to hold the U.S. forces on the peninsula (Kim 2011; Zhihua 2000; 2013; Weathersby and Kang 2010; Zhihua and Xia 2017). Throughout the war, Stalin had only considered his national interest, not those of his Communist allies, the Chinese and North Koreans. The war finally stopped when Stalin died in 1953. To answer these questions, I used primary and secondary sources from Russia, as well as interviews with former KPA soldiers.

\section{STALIN'S COLD WAR STRATEGY IN NORTHEAST ASIA}

Military historian Adrian R. Lewis (2017) described the psychological situation of the Soviet people after the end of the Second World War. Lewis argues that 
the war severely traumatized the Soviet people, as 25 to 30 million lives were lost. Many also directly experienced the brutality of war and witnessed the total destruction of their cities and homes. Russian military historian David R. Stone (2010, 2-3) wrote that, for every American or British soldier who perished, twenty Soviet soldiers died; furthermore, "one thousand Soviets died every hour of every day of every month of every year from June 1941 to May 1945." As a result of this violence and massive destruction, the Soviet leadership basically wanted to concentrate on national recovery, both economically and psychologically, immediately after the war. Therefore, the Soviet Union sought to create large security buffer zones in order to protect themselves from future foreign threats. Stalin's concern was not fantasy because Winston Churchill and the British Joint Planning Staff developed Operation Unthinkable to invade the Soviet Union along with the United States, Germany and Poland after the defeat of the Nazis (Reynolds 2006; Walker 2013).

As Stalin watched U.S efforts to rebuild Europe, including West Germany, with the Marshall Plan, his concerns about another war in Europe increased significantly. Stalin wanted buffer zones to guarantee their security from future threats from the United States, Germany, and Japan. Nationalism and realpolitik were more important than an idealized revolutionary brotherhood. After the Second World War, the Soviet Union's top priority was to rebuild the national economy rather than starting another war (Roberts 2006). In foreign policy, Stalin was a pragmatist who weighed options and carefully made decisions. Harrison E. Salisbury $(1969,93)$ argued that Stalin was not a gambler but a cautious man: "Stalin never played power politics in a random fashion, Stalin's decision regarding the Korean War was only within the framework of a calculated means to an end." Stalin had a stroke in 1945 and suffered from illness until his death in 1953. On the other hand, Mao and Kim Il Sung in 1950 were young revolutionary romantics (Van Ree 1989).

The Soviet Union historically had been very weak in the Far East. Without the United States' Lend Lease program, the Soviet Army could not have conducted their military operations in Asia during the Second World War. More than 50 percent of logistics and supplies for the Soviet Army during the Second World War were from the United States. However, Stalin knew that the United States largely demobilized its army in 1950. In 1950, the Soviet Army was generally much stronger than the U.S. Army in terms of ground forces, as Stalin had halted the postwar demobilization of the Soviet armed forces. The Soviet Army doubled in size between 1948 and 1955 (Roberts 2006). ${ }^{2}$ Nonetheless, Stalin recognized

${ }^{2}$ By the late 1940s, the Soviet Army numbered around three million in 175 divisions, down 
that the Soviet Army would not win a war on the Korean Peninsula due to U.S. naval supremacy and air power. Thus, Stalin decided that the Far East was not the ideal place for a showdown between Soviet and U.S. forces.

Stalin was also concerned about the rise of the People's Republic of China in Northeast Asia. Mao took control of Mainland China after the Chinse Civil War, not because of Stalin but in spite of him. Stalin had a reliable man, Kao Kang, in Manchuria to replace Mao. Due to Kao Kang's close connections with the Kremlin, Mao feared his influence. Two years after Stalin died, Kao Kang committed suicide (Salisbury 1969). At that time, Beijing targeted Kao Kang and other pro-Soviet Chinese politicians for being Soviet spies. Due to the relatively tense relations between Mao and Stalin in the late 1940s and early 1950s, the Kremlin calculated the benefits and risks of the Korean War and the possibility of U.S. intervention. During the war, Stalin never replied to the letters from Beijing that discussed an early Chinese intervention in July 1950 that would have guaranteed a quick victory for the communist forces, as Chinese intervention would have blocked the building of a U.S defensive line along the Pusan Perimeter (Zhihua 2010; 2012). ${ }^{3}$ Instead, Stalin asked the Chinese to intervene in October 1950 after the UN forces nearly crossed the $38^{\text {th }}$ parallel and KPA forces were being decimated. Stalin also delayed sending air support to aid PRC forces, which he had promised earlier.

In Stalin's global strategy, the Korean conflict was not only a useful litmus test for the Americans, as it challenged their willingness to protect their allies, but also the Korean conflict was an opportunity to get the United States and China involved in a significant war that would consume the attention and energy of both states. This was a gamble, but regardless, no Soviet blood would be spilled in the war. In a protracted war, the Chinese and North Koreans would pay with their lives more and more. Stalin did not see the young and inexperienced leader Kim Il Sung as a serious and equal partner. In this context, I argue that Stalin's strategy towards the Korean War was aimed at maximum gains while minimizing risks.

Stalin skillfully had manipulated the situation for his own interests since the beginning of the war. When Kim Il Sung and the KPA stayed in Seoul for three days from June 28 to 30 at the start of the war, Stalin waited to tell Kim that the KPA should advance quickly before UN forces arrived in Pusan. ${ }^{4}$ According to

from 11 million in 500 divisions in 1945.

${ }^{3}$ Chinese scholar Shen Zhihua found Chinese sources acknowledging the eagerness of the PRC leadership to intervene in early July 1950, but Stalin refrained from giving the necessary approval.

${ }^{4}$ President Truman decided to send forces to Korea on June 27, 1950. 
the Soviets' war experiences in the European theater, and a military doctrine of the Soviet Union known as 'Deep Operation,' Stalin and Soviet advisors knew that this strategy brought the greatest likelihood of success at an early stage. The KPA should have advanced as soon as possible and not stayed in Seoul for three days. Stalin eventually advised Kim to move southward. If Soviet forces were in Korea, Stalin would certainly have pushed forward and ordered his front-line commanders to not waste a second in advancing towards Pusan. Due to the KPA's three-day stay in Seoul, the UN forces had sufficient time to arrive in Pusan. In particular, General Pang Ho San's division, one of the best units of the KPA, went to Jeolla Province and then Pusan, a long detour and the exactly opposite of the Soviet style of operation known as Deep Operation (Kim 2017). According to Deep Operation, most of the KPA forces, including Pang's division, should have gone directly to Pusan as soon as possible because that was what was typical of the Soviet's Deep Operation strategy during the Second World War. The Soviet Army finally won the war against the Nazis in Europe and the Japanese in Manchuria because of the successes of Deep Operation, including the Kursk Battle and Operation August Storm in Manchuria (Glantz and House 1999; Glantz and House 2015; Glantz 1991a; 2001a; 2001b; 2003; Glantz and Orenstein 1999). Nonetheless, KPA forces did their operations in opposition to Deep Operation, and the Soviet advisors kept silent even though they were masters and veterans of Deep Operation.

More importantly, Stalin manipulated the timing of the Chinese intervention. Stalin never replied to Beijing's letter that 320,000 Chinese forces were ready to intervene for a victory in early July 1950 (Zhihua 2012). Militarily, this would have assured a swift victory, but Stalin feared Chinese influence over the Korean Peninsula after the war. Thus, Stalin okayed Chinese intervention much later in the war, when North Korean forces were on the brink of defeat. Stalin asked Mao to intervene in the Korean War only after U.S. forces nearly reached the Yalu River, the border between the PRC and North Korea. Mao hesitated but finally decided to enter the war and sacrificed the lives of his countrymen, including his own son's.

During the war, Stalin and Soviet advisors never advised Chinese or North Korean leadership and continually kept silent when Kim Il Sung made crucial mistakes regarding the use of military forces. For instance, Kim Il Sung divided the KPA into two lines when his forces advanced towards Pusan. Kim ordered the KPA's Sixth Division, his strongest unit mostly consisting of veterans from the Chinese Civil War, to advance a support line towards Jeolla province where no enemies existed. This was a huge mistake militarily and in opposition to Soviet operational doctrine. However, Kim Il Sung was an inexperienced young 
leader who put his political interests first over his military interests, as the Sixth Division consisted of pro-China veterans, potential rivals of Kim's after the war. Nonetheless, hundreds of Soviet advisors who were close to Kim, including many generals and veterans who fought with the Soviets against the Nazis, continually kept silent regarding this crucial mistake. These more experienced Soviet advisors clearly knew this mistake could potentially lose them the war. Due to this operational mistake, the UN forces and the South Korean Army had sufficient time to build a strong defensive line (Kim 2017).

Stalin closely observed the U.S. air power during the Korean War, as hundreds of Soviet military pilots fought against U.S aircraft near the border between China and Korea (Zhihua 2010). Stalin knew that the Soviet Union lagged behind the U.S. air power, so he quickly developed the Soviet aircraft industry, including radar and air defense, between 1951 and 1953. However, the Soviet air force was still weaker than U.S. air power, which meant Stalin could not achieve his ultimate goal of bombing the United States in the near future with atomic bombs (Zubok 2007). The Korean War was a good case study for the Soviet Union in testing the U.S. air power, military capabilities, and resolve.

Throughout the armistice talks, Stalin wanted to delay the war as long as possible to hold the U.S. forces on peninsula, even though Kim Il Sung wanted to stop the war as soon as possible because of the U.S. strategic bombing campaign on industrial centers (Kim 2017). Although many North Korean civilians unnecessarily died, Stalin had little regard for the safety of his Korean comrades. Stalin lured his enemies and junior partners into a dangerous position and kept them there as long as he could (Kim and Stueck 2008; Filipov 1950). The price of a protracted war was Chinese, American, North and South Korean casualties, not Soviet ones.

By making the Korean War longer and focusing the U.S. power on the Korean Peninsula, Stalin sought to delay a third world war in Europe and give the Soviet economy sufficient time to recover from the devastation of the Second World War. From the Korean War, Stalin gained a security buffer zone for the Soviets in the Far East with no serious loss of Soviet lives. As the U.S. President Eisenhower was becoming increasingly concerned that atomic weapons would have to be used in Korea, the Korean War mercifully stopped when Stalin died in 1953.

\section{THE SINO-SOVIET TREATY AND STALIN'S GLOBAL SECURITY STRATEGY}


Previous studies have mentioned that the relationship between Mao and Stalin was complex and strained (Zhihua and Li 2011; Zhihua and Xia 2017; Zhihua 2000; 2013). They maintained a troubled partnership which developed into the Soviet-Sino split several years later after Stalin's death, although the Soviet-Sino split originated from tensions between Mao and Khrushchev. During the Chinese Civil War, Stalin negotiated with Mao's enemy, the Chinese Nationalists. The Soviet Union and China were ideological allies but their interests and strategies were different. Although the later split between the Soviet Union and China was ultimately caused by ideological disagreements, the interests of Stalin and Mao were also at odds.

Stalin's greatest fear was that Mao would establish closer ties with Western countries. This complicated partnership began when Mao won the civil war (Zhihua and Li 2011). However, in order to set up the new political geography of Northeast Asia, negotiations between these two communist leaders was critical. Despite his personal dislike of Mao, Stalin had to make Mao his close ally, and not America's partner, in order to achieve the Soviet Union's long-term goals.

Stalin agreed to Kim Il Sung's invasion plan while the Soviet leader was in the middle of negotiating the friendship treaty with the PRC. After Stalin's decision to concede in early January 1950, Zhou Enlai came to Moscow on January 20 and he and Mao had a talk with Stalin on January 22. The talks were mainly between Mao and Stalin, and Zhou only attended as a member of China's delegation. On January 26, China proffered a draft agreement that asked the Soviet Union to completely withdraw from Lushun, Dalian and the Chuangchun Railroad within three years. Stalin was surprised that China not only asked Soviet troops to withdraw from Lushun but also to give up the Soviet Union's privileged positions in Northeast China. The Soviet Union revised this Chinese draft on January 28, which was revised by the Chinese from January 31 to February 2 (Zhihua and Li 2011). During this same period, Stalin agreed to permit Kim to launch an invasion of South Korea (Weathersby 1995b). Before this, Stalin had rejected Kim's plan multiple times because of his fear of U.S. intervention and North Korea's unpreparedness for war. Stalin never explained why he changed his thinking. However, Stalin and other Soviet elites may have worried that an unprepared North Korean invasion of the South would lead to a major crisis with the United States. At the end of January, Stalin's top concern was drafting the new agreement with China. To Stalin, this treaty would set up a new political geography of Northeast Asia. Two days after reading China's bold draft, Stalin sent his permission to Kim Il Sung without stating the reasons why he changed his mind. Finally, on February 14, the Soviet Union and China officially signed a new agreement in which Stalin made a concession to give 
up the Soviet Union's previous rights to Lushun, Dalian, and the Chuangchun Railroad. As the Soviet Union already had Mongolia as a major partner in Northeast Asia, Stalin was willing to make a concession in his mapping of Cold War political geography (Zhihua and Li 2011).

During the period of negotiation with China, Stalin rethought his strategic objectives in Northeast Asia within the framework of Cold War geography. Stalin expected that, regardless of a North Korean victory, only U.S. intervention was going to be enough to spur China to ask the Soviet Union to stay at Lushun port, and his expectation was realized in September 1952. Also, Korea was a good chess piece for Stalin's new game in shaping a new Cold War geography. Stalin asked Kim Il Sung to get the Chinese to promise to help the North Koreans if the United States intervened in the Korean conflict. If Kim Il Sung won the war, Stalin would get an ice-free port and a railway to the Pacific Ocean in Korea. If Kim Il Sung lost the war, Mao would ask Stalin for Soviet forces to defend against a possible U.S. or Japanese attack on Manchuria (Zhihua and Li 2011). To Stalin, the Korean War was a cheap gamble with little risk that would prevent a Sino-American alliance and military conflicts in Europe and Taiwan. Mao's trip to Moscow was a significant event that altered Stalin's geostrategic thinking towards Northeast Asia.

\section{THE MILITARY QUESTION: DID STALIN NOT WANT A QUICK VICTORY FOR THE KPA?}

Through Soviet guidance and support, the KPA transformed into a relatively powerful military force between 1945 and 1950. However, the Soviets led the KPA astray during the Korean War as Soviet planners put their national interests ahead of KPA success (Kim 2017). Soviet war planners hoped for no intervention from the United States and a rapid collapse of the South Korean government. However, in doing so, they planned with the best possible scenario in mind. Why did they do this in that way? Is it because they had an overly optimistic outlook, just like the young and passionate Kim Il Sung? This plan was based not on their professionalism and work ethic, but on the immature optimism of Soviet war planners. The plan of attack was designed by Soviet advisors and later translated by KPA officers (Ju 1990; Jang 1991). ${ }^{5}$ Frequently throughout history, wars were

5 Former KPA officer Ju Young Bok remembers that he translated the Russian language invasion plan and it was made by the Soviet advisors from his memoir. Ju Young Bok was a Russian 
won after a capital was seized. Soviet advisors and Kim Il Sung designed and built the KPA to defeat an unimpressive South Korean army. Initially, the KPA had success in the Korean War due to its modern, offensive tanks and artillery.

Second, the epistemology of financial governance is concerned with undSeveral scholars have argued that what enabled a significant distinction beeir short-term debdge that the aggregate is more than the sum of its individual parts and "social entities and forces ... possess an autonomous standing" (Baker and Widmaier 2015, 376-377).

Interestingly, when the war plan was being determined in a secret situation room before the war, Kim Il Sung and his Soviet advisors did not allow Korean veterans of the Chinese Civil War, and many of them were prominent KPA officers. The Soviet Union also kept the timing and the process of the invasion secret from the Chinese until the beginning of the war (Yu 1990; Kim 2017). ${ }^{6}$ Mao was informed of the start of the war by reading a newspaper. Kim Il Sung believed the big talk of Park Hun Young, a foreign minister and former leader of the South Korean Workers' Party, about the improbability of U.S. intervention. However, this amateur plan did not make sense to the professional military officers who had extensive battle experience. Jang Jun Ik, a retired lieutenant general with the Republic of Korea (ROK) Army who published a book on the KPA and the Korean War, estimated that the plan, which only had an initial operational scope for the occupation of Seoul, was complete and utter nonsense from a military perspective. However, the KPA tanks did not cross the Han River from Seoul in force until July 3, the eighth day of the war (Higgins 1951).

Was it possible that the planners thought this war was similar to the recent war fought by the Soviet Union against Nazi Germany, and when did it finally became apparent that the United States was going to intervene? Speed was only necessary if the United States came to support South Korea. I argued that Stalin actually used and abandoned the KPA. Stalin saw KPA forces as useful pawns for his larger goal of igniting a U.S.-China conflict to help prevent a more decisive war between the Soviet Union and the United States in Europe. If the United States and China were to become hostile, China's dependence on the Soviet Union was expected to increase. If Kim won the war, Stalin would have also benefitted from the acquisition of seasonably warm water ports and a small security buffer zone. Even if Kim was defeated in the Korean War, the

translator and a deputy chief of the Engineer Section of the KPA's Second Corps.

${ }^{6}$ Former KPA officer Yu Song Chul remembers that no Korean-Chinese veteran officers, who fought during the Chinese Civil War, were allowed to enter the secret situation room or see the invasion plan. 
relationship between China and the United States would become hostile due to the war, and thus would delay any thaw in U.S.-PRC relations indefinitely. This fit into Stalin's grand strategy, while shifting the costs of war onto Mao and Kim. It was a win-win scenario for Stalin. Arguably, Stalin set the stage for a U.S.PRC confrontation on the Korean Peninsula and benefitted from the slaughter of Chinese and American soldiers on the battlefield. Throughout the three-year war, Stalin maintained this same attitude.

Operationally, the KPA did not resemble the traditional Soviet style of miltiary organization. One tank brigade was too small for conducting a Soviet-style deep operation. For a deep operation, first echelon units should be organized to conduct the Soviet way of war. According to the Soviet General Staff, the duty of the civilian economy and national defense industry was to assist the military forces at the front. All resources went to supporting those soldiers on the frontlines. The General Staff and GOSPLAN traditionally saw the entire nation as contributing towards the war effort, including logistics, supply, manpower, and transportation. The KPA did not focus the national economy on singlehandedly assisting the military. The traditional Soviet way of waging war was a penetration of mobile forces by using first, second and third echelons (Glantz 1991a). The objective was not capturing territory, but rather destroying the enemy's forces (Glantz 1987; 1991b; 1991c).? The KPA did not have enough mobile forces to conduct a deep operation. Stalin avoided taking direct responsibility in the Korean conflict and directed Mao to take responsibility for the war effort.

Figure 1. The Soviet 'Deep Operation' Strategy ${ }^{8}$

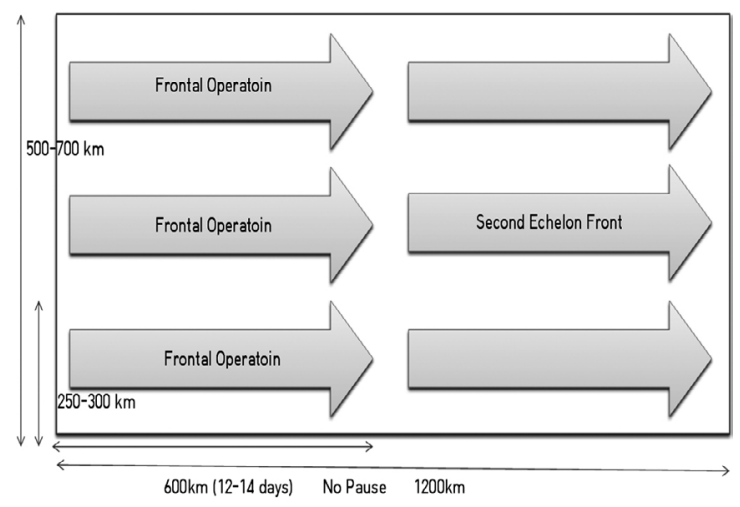

${ }^{7}$ In numerous books and articles, Glantz well explained the Soviet way of war and the 'Deep Operation' strategy.

${ }^{8}$ I created this table to explain the Soviet Army's operational concept of 'Deep Operation'. 
As Figure 1 shows, a key element of the typical Soviet deep operation that had been conducted very successfully in the European theater against the Nazis and in Manchuria against the Japanese was the emphasis on maximum speed without stopping. A frontal assault was to strike 600 kilometers deep inside enemy territory, and then a subsequent wave was to immediately strike another 600 kilometers deeper. Each strike usually lasted from 12 to 14 days at maximum speed, and there was to be no pause between the first wave of attack and subsequent operations (Odom 1998). This maximum-speed series of offensives without pause was designed to shock the enemy and cause panic. The key factor of the Soviet's victories during World War II was the military's endless offensives. These massive offensives destroyed the German Army in Europe and the Japanese Army in Asia during the Second World War. The Soviet generals, veterans of the Second World War, were masters of the deep operation and experienced in how to win a war. The interesting thing was that the KPA's initial operation during the Korean War was not a Soviet-style deep operation. In fact, the opposite was true. In past studies, historians of the Korean War who were not familiar with military operations and the Soviet deep operation strategy for fighting, unanimously explained that the KPA's initial operations were the same style of Soviet operation because the KPA used T-34 Soviet tanks and Soviet military advisors designed the invasion plan. However, the KPA stopped in Seoul after three days and spent three days in capital. Even the Sixth Infantry Division of the KPA, General Pang Ho San's division and the strongest of the KPA, arrived at Kimpo Airport on June 28 and stayed for about a week until July 3 when the North Korean army then entered Seoul. Choi Tae Hwan, who was a political commissar of the KPA's Sixth division, stated that his division stopped at Kimpo even though there had been little defense from ROK forces and few logistical problems (Han 1988). This was opposite to the Soviet style of deep penetration during the initial attack. The Korean Peninsula's small size was not a problem, but stopping for the initial period of the war was unimaginable for the Soviet Army. If the KPA had been the Soviet Army, the Kremlin and Soviet military advisors would have pushed the KPA every minute to maximize its speed to prevent the arrival of the UN forces. However, Soviet military advisors in Pyongyang kept silent for three days. Why did the Soviet advisors not design an invasion plan based on their successful deep operation in order to stop the arrival of UN forces and achieve a quick victory? If the KPA had conducted a Soviet-style deep operation and kept advancing to Pusan based on the order of maximum speed, the war would have been over before the arrival of UN forces.

Mikhail Tukhachevsky (1921; 1927; 1930; Kokoshin 1995) created the concept of 'Deep Operation,' although Stalin had Tukhachevsky purged and delayed 
development of the operational concept in the Soviet Army until the Seond World War. During the war, the Soviet Army successfully mastered 'Deep Operation,' and this helped win the war (Glantz and House 2015; Glantz 1998; 2005). Typically, Soviet ground forces never stopped their advances for 1,200 kilometers during three-to-four-week periods of advance. Soviet military advisors conducted deep operations hundreds of times in hundreds of battles during the world war. Most of their operations were successful, and the Soviet army was very proud of their strategy. Historians who have understood the KPA's operation as following the Soviet style of war just because the KPA used T-34 tanks and had Soviet advisors have misinterpreted the KPA battle strategy. It was possible that the North Korean leadership's singular objective was to occupy Seoul as a limited war. Nonetheless, when the war began and the United States decided to intervene, Soviet military advisors naturally had to advise the KPA to keep pushing southward at maximum speed to prevent the arrival of UN forces. However, Soviet military advisors kept silent and maintained a wait-andsee attitude during this most important period of the war. This allowed time for UN forces to arrive in Pusan and for the ROK armed forces to reorganize and dig in. The Kremlin and Soviet military advisors already knew that the KPA had to continuously advance at maximum speed to reach Pusan if the KPA wanted a quick victory without the possibility of intervention by foreign troops. However, the Kremlin and its military advisors did not plan an invasion for a quick win and even did not advise the KPA for the three days when the KPA stopped and waited in Seoul, which was a key turning point of the war (Kim 2017). From a military point of view, the silence of Soviet military advisors, who knew how to win a quick victory, was intentional because they had conducted hundreds of battles following the deep operation strategy just a few years earlier during World War II.

For instance, the Soviet Army never stopped its four-year advancement through Eastern Europe and its strategic offensive of Operation August Storm in Manchuria near the end of the World War II. The key element of the Soviet Army's victory was advancement at maximum speed without any stopping for the first couple of weeks (Tukhachevsky 1921; 1927; 1930; Glantz and House 3015; Glantz 2003). ${ }^{9}$ The KPA initiated its advancement for the first few hours

9 Mikhail Tukhachevsky designed the Soviet's 'Deep Operation' attack strategy based on maximum speed and penetration without stopping its advancement in order to shock and put fear into enemy units. His major works include Voina Klassov (War of the Classes), "K voprosu o sovremennoi strategii" ("On the Question of Modern Strategy") in Voina i voennoe iskusstvo v svete istoricheskogo materializma (War and the Art of War in Light of Historical Materialism) and "O kharaktere sovremennykh voin v svete reshenii VI Kongressa Kominterna" ("On the Character of Modern Wars in 
according to the invastion plan, but quickly stopped for a few days after reaching Seoul. This was the most important time for achieving victory in the war (Kim 2017; Jang 1991).

The Kremlin recognized the capabilities of the KPA on the eve of the war and knew how to guide the KPA according to the Soviet's operational concept of deep operation. The following Russian document is the correspondence of Soviet Deputy Foreign Minisiter Andrei A. Gromyko to the Soviet Ambassador in Pyongyang Gerentii Shtykov on May 31, 1950, just a few weeks before the outbreak of the war.

что их пехотные войска готовы вести боевые действия. Из 10 пехотных дивизий семь уже были полностью готовы к проведению наступательных операций. Танковая бригада и мотоциклетный полк тоже готовы. Три новых стрелковых дивизиона заканчивают обучение в июне. Это их устраивает, так как они предназначены для второго эшелона (Archive of the President of the Russian Federation (APRF, 1950).

In this correspondence, the Kremlin explained that the 10 infantry divisions, tank brigade, and motorcycle regiment of the KPA were ready to conduct offensive operations, and this meant that the KPA was designated for the "second echelon." The term "second echelon" is a key, and unique, term in the Soviet Army's deep operation strategy. A few weeks before the beginning of the war, not surprisingly, the Kremlin and its Soviet military advisors-including Ambassador to Pyongyang Shtykov-fully understood the capabilities of the KPA and how to use the KPA as a first and second echelon strike force according to the deep operation concept that the Soviets had mastered. The problem was, when the KPA began its movement during the Korean War, the KPA did not follow the deep operation style that the Soviet Army and military advisors mastered. Instead, the opposite was true.

In addition to these operational issues, scholar Shen Zhihua (2010) found Chinese sources that detailed Stalin's reluctance to allow Mao to intervene at an early stage of the Korean War. Mao wanted to intervene in the war with 320,000 soldiers before UN forces advanced northward. In addition, Kim Il Sung wanted Chinese assistance as soon as possible due to the near-continuous U.S. strategic bombing in the North. However, Stalin did not reply to the request from Mao and Kim during the early stage of war. If Chinese troops intervened in early July

Light of the Decisions of the Sixth Commintern Congress"), in Zapiski Kommunisticheskoi Akademii (Proceedings of the Communist Academy). 
with Stalin's consent, the situation of the war would have been dramatically different. Before Chinese troops crossed over the Yalu River, the KPA was close to the point of total destruction as the United States and the ROK armies pushed northward to the river. Stalin, as the mastermind of the communist war effort, timed Chinese intervention to occur when the KPA was on the brink of collapse. Stalin had even recommended to Kim Il Sung to flee the Democratic People's Republic of Korea if the situation worsened. ${ }^{10}$ Stalin advised Kim that he may have to abandon his revolution.

These military points support the hypothesis that Stalin did not want a quick victory for the KPA in this small civil war on the Korean Peninsula. Rather, he fundamentally expected a protracted internationalized conflict to evolve by delaying the KPA's push to Pusan in order to lure the United States into intervening. Thus, from this military point of view, I argue that the Kremliln waited and lured the United States to intervene militarily in this small civil war in order to maximize Soviet interests, and so wanted to reshape this small civil war into a long, internationalized war that pitted the PRC against the United States.

\section{STALIN'S MAXIMUM GAIN / MINIMUM RISK SECURITY STRATEGY"}

On August 27, 1950, Stalin told CSSR leader Llement Gottwald his secret strategy:

Во-первых, Америка, как и любое другое государство, не может справиться с Китаем, имеющим на готове большие вооруженные силы .Стало быть , Америка должна надорваться в этой борьбе .Во-вторых, надорвавшись на этом деле , Америка будет неспособна в ближайшее время на третью мировую войну. Стало быть, третья мировая война будет отложена на неопределенный срок, что обеспечит необходимое время для укрепления социальзма в Европе. Я уже не говорю о том, что борьба Америки с Китаем должна будет революционизировать всю Дальневосточную Азию.Дает ли все это нам плюс с точки зрения баланса мировых сил? Безусловно дает (ФИЛИППОВ.27 августа 1950г) (Russian State Archive of Socio-Political History, 1950).

\footnotetext{
${ }^{10}$ Some of Kim's family did, in fact, flee to Manchuria.

${ }^{11}$ Bruce Cumings (1992) was the first to use this expression of Stalin's maximum gain / low risk strategy.
} 
This correspondence states, "America would overextend itself in this struggle and America would be incapable of a third world war in the near future. Therefore, a third world war would be postponed for an indeterminate period, which would provide the time necessary to strengthen socialism in Europe" (Filipov (Stalin) 27 August 1950). Stalin believed that the United States would not start another war in the near future due to its reduced military capabilities, especially the loss of ground forces committed to the Korean War (Kim 2011). The U.S. Army was not prepared for another war in Europe. In the late 1940s, the U.S. government worried that the Soviets would attack Europe and Taiwan. The United States lacked large enough ground forces to defend against a preemptive strike from the Soviet Union (Zubok 2007; Lewis 2017). After the Second World War, the number of the U.S. ground forces was largely reduced, while the Soviet Union maintained its large ground forces. Although Stalin worried about the possible outbreak of another war by the United States after the North Atlantic Treaty Organization was established, Stalin recognized this advantage of ground forces size over the United States.

Nikita Khrushchev recalled, "Our advisers, when they planned this operation, probably did not take everything into account and did not give everything needed ... I think if Kim had received just one more tank corps, or two at the most, he could have accelerated his advance south and occupied Pusan on the march. The war would have ended then and there" (Thornton 2000, 408; Shechter and Luchkov 1990, 146; Talbott 1971, 370). It was speculated that Khruchchev wanted to blame everything on Stalin for political reasons. However, evidence supports Khruchchev's assumptions. According to Yu Seongchul's testimony, Kim Il Sung expressed dissatisfaction with his own minister about a lack of Soviet support for large-scale river crossing equipment for troops crossing the Han River (FBIS 1990, 29). ${ }^{12}$ Recently, North Korean defector Jang Jin sung, who was one of the official authors of the Official History of North Korea, testified that Kim Il Sung openly blamed Stalin for the Korean War at the Korean Workers' Party Conference in 1976 (Jang 2013). Kim Il Sung also might have been trying to minimize his responsibility for the failures of the war.

Stalin continually maintained his low risk/maximum gain strategy during the Korean War. It is unknown whether Stalin expected the United States to intervene in the war, but he gave a free hand to the United States at the UN Security Council meeting authorizing the use of force to defend South Korea,

${ }^{12}$ Yu Song Chul was Major General Operation Bureau Commander of the KPA General Staff during the Korean War and was freed from North Korea to Russia later because of Kim Il Sung's purges. 
and he maintained his low risk/maximum gain strategy when the United States decided to send ground forces to the Korean Peninsula. Stalin bolstered the KPA's advancement without additional direct support. During the armistice process, Stalin ordered the Chinese and North Korean leaders to delay the negotiations as long as possible in order to keep the U.S. forces in Korea. Kim Il Sung initially asked for an armistice agreement in 1951 because he worried about the decimation of KPA forces and the continuous the U.S. strategic bombing of North Korean industrial centers (Kim 2017). Nevertheless, Stalin never allowed for an armistice, which was only concluded after his death. In a meeting with Kim Il Sung in Moscow when Stalin called Peng Duhuai and Kim Il Sung for a talk about an armistice, Stalin told them that Norh Korea and China should not accept any offers from the U.S. side and delay the negotiations as long as possible. Stalin thought it would be strategically beneficial for the Soviet Union if North Korea and China kept U.S. forces in Korea for as long as possible, even if it meant large numbers of North Korean and Chinese casualties (Rozas and Weathersby 1995) ${ }^{13}$ China and the Soviet Union had multiple motives to let the war continue, while the United States had many reasons to want to end the war. China wanted to train and rearm the People's Liberation Army. As long as the Chinese Volunteer Forces engaged, China would receive more military assistance from the Soviet Union. Because many soldiers in the CVF were former Chinese Nationalist Army soldiers. Mao did not care about the number of Chinese casualites during the Korean War (Millett 2010).

During the Korean War, Kim Il Sung was humiliated by the U.S. and the ROK forces. However, he was more shocked by the delayed assistance from his allies, the Soviet Union and China. Thus, it was no surprise that Kim Il Sung later purged pro-Soviet and pro-Chinese elements in 1956, after the war. Kim's humiliation also motivated him to focus on self-reliance after the war, which led to the creation of the 'Juche' ideology.

Stalin's basic assumption was that the United States would intervene in the war in Korea. Thus, Stalin made clear to Kim Il Sung that if the United States intervened, the Soviet Union could not offer direct assistance, and so China must intervene in the war. Stalin believed that the United States would intervene, but he did not want a third world war caused by conflict shifting from the Korean Peninsula to the Chinese mainland. Stalin was also concerned that U.S. military leaders, such as Curtis Le May, would seek to destroy China and the Soviet Union with nuclear weapons. As Stalin knew, only the United States had the

${ }^{13}$ See Transcripts of Conversation between Stalin and Zhou Enlai held August 20, September 3 and September 19, 1952. 
means of delivering such weapons in the early 1950s, only the United States had used atomic bombs, and only the United States had destroyed cities with bombs, such as the fire bombings of Tokyo and Dresden. Stalin knew about these capabilities and clearly wanted to use the Korean War for his own broader interests when the United States decided to send ground forces to Korea. After the U.S. intervention, Stalin did not care if the KPA won the war or not. At that stage, Stalin's political and strategic objectives were to make the Korean War a U.S.-China conflict that would drain the energy, manpower, and coffers of Washington, which would mean a lower possiblity for another war in Europe. At the same time, the U.S.-China conflict effectively made China into a large buffer zone for the Soviet Union against threats from the United States and Japan, as the Russian Far East had historically been treated as a defensive weakness for Russia (Lewis 2017). From this war, Stalin achieved a great security buffer zone for the Russian Far Eastern at very little cost. Table 1 below shows Stalin's strategic calculations for this limited war before the U.S. intervention.

Table 1. Stalin's Maximum Gain / Low Risk Strategic Calculations for the Korean War

\begin{tabular}{|c|c|c|}
\hline Scenario & Gains to Stalin & Risks to Stalin \\
\hline $\begin{array}{l}\text { If the KPA wins the war } \\
\text { without Chinese intervention }\end{array}$ & $\begin{array}{c}\text { Buffer zone against } \\
\text { U.S. and Japanese threats }\end{array}$ & None \\
\hline $\begin{array}{l}\text { If the KPA loses the war } \\
\text { without Chinese intervention }\end{array}$ & None & $\begin{array}{l}\text { South Korea supported by the United } \\
\text { States with contiguous borders with } \\
\text { the Soviet Union, although Stalin } \\
\text { already had a strategic reserve area } \\
\text { against U.S. and Japanese threats } \\
\text { in Manchuria }\end{array}$ \\
\hline $\begin{array}{l}\text { If the KPA wins the war } \\
\text { with Chinese intervention }\end{array}$ & $\begin{array}{l}\text { Buffer zone against U.S. and } \\
\text { Japanese threats + U.S.-China } \\
\text { Conflict + No major war in } \\
\text { Europe near term }\end{array}$ & None \\
\hline $\begin{array}{l}\text { If the KPA loses the war } \\
\text { with Chinese intervention }\end{array}$ & $\begin{array}{l}\text { U.S.-China conflict + No major } \\
\text { war in Europe near term }\end{array}$ & $\begin{array}{l}\text { South Korean + the US forces on its } \\
\text { border; South Korea supported by } \\
\text { the United States with contiguous } \\
\text { borders with the Soviet Union, } \\
\text { although Stalin already had a } \\
\text { strategic reserve area in Manchuria. }\end{array}$ \\
\hline $\begin{array}{l}\text { If no winner in the war } \\
\text { with Chinese intervention }\end{array}$ & $\begin{array}{l}\text { U.S.-China conflict + No major } \\
\text { war in Europe near term }\end{array}$ & None \\
\hline
\end{tabular}




\section{CONCLUSION}

During the war, the American perception of Stalin's intentions and motivations for the war were far from the reality. Americans regarded the Korean War as the Soviet Union's war and well-controlled by the Kremlin. However, the Korean War was neither Stalin's war nor a strictly Kremlin-controlled war as Washington wrongly assumed (Kissinger 1994). Stalin and the Soviets looked carefully at every detail and process of the war but there were limited actions made by advisors (Kim 2017). The Soviet Union's aim mainly was to prevent a third world war and limit the scope of major conflict with United States. ${ }^{14}$ In the early stage of war, Stalin rejected Mao's early intervention, which would have guaranteed a quick victory for Kim Il Sung. When U.S. forces reached the Yalu River, Stalin suggested to Kim Il Sung that he should give up the war and flee from his country. Stalin did not want to lose anything from this war. Stalin wanted to avoid a direct war with the United States and, at the same time, maximize gains from this small conflict that involved the newly-emerging power China and the world's hegemon, the United States (Kissinger 1994, 487). During the early stages of the Cold War, the Korean War played an important role in the shaping of a new world order. From this war, the United States and the Soviet Union maintained an artificial limited war in order to avoid nuclear war (Lewis 2017). Stueck $(2002,1)$ was right in saying, "the Korean War was international history and a substitute for the Third World War." The Koeran War was a win-win scenario for Stalin. From the KPA's performance, which ran counter to the Soviet Army's operational concept, 'Deep Operation,' and the silence of the Kremlin and Soviet military advisors at the initial stage of the Korean War, it is clear that Stalin wanted bigger strategic benefits than a quick victory on a small peninsula in the Far East.

\section{REFERENCES}

Archive of the President of the Russian Federation (APRF).“Telegram from Soviet Ambassador in Pyongyang, Report on a Meeting between

${ }^{14}$ Woodrow Wilson International Center for Scholars has numerous Russian documents that show how the Soviets managed many details of the war effort during the Korean War, including changing the chain of command and disapproving movements to the South. Recent declassified reports by the former Soviet defense attaché and ambassador Razubaev show how Soviet advisors evaluated and checked the performance of the KPA during the war. 
Shtykov and Kim Il Sung." (May 30, 1950), History and Public Policy Program Digital Archive, Library of Congress, Manuscript Division, Dmitriǔ Antonovich Volkogonov papers, 1887-1995, mm97083838.; Archive of the President of the Russian Federation (APRF). Translated by Gary Goldberg. Accessed at https://digitalarchive.wilsoncenter.org/ document/114908 (April 7, 2019).

Cummings, Bruce. 1992. The Origins of the Korean War, Volume 2: The Roaring of the Cataract, 1947-1950. Princeton, NJ: Princeton University Press.

FBIS. 1990. "Yu Song-chol's Testimony." (December 27). Foreign Broadcast Information Service - East Asian Survey (FBIS-EAS). Washington D.C.: Central Intelligence Agency, Part 10.

Glantz, David M. 1987. The Soviet Conduct of War. Fort Leavenworth, KS: Soviet Army Studies Office.

. 1991a. The Soviet Conduct of Tactical Maneuver: Spearhead of the Offensive. London and New York: Routledge.

. 1991b. Soviet Military Operational Art: In Pursuit of Deep Battle. Fort Leavenworth, KS: Frank Cass.

. 2001a. Soviet Military Operational Art: In Pursuit of Deep Battle. London and New York: Routledge.

. 2001b. The Military Strategy of the Soviet Union: A History. London and New York: Routledge.

. 2003. The Soviet Strategic Offensive in Manchuria, 1945: 'August Storm'. London and New York: Routledge.

Glantz, David M., and Jonathan M. House. 1999. The Battle of Kursk. Lawrence, KS: University Press of Kansas. . 2015. When Titans Clashed: How the Red Army Stopped Hitler. Lawrence, KS: University Press of Kansas.

Glantz, David M., and Harold S. Orenstein. 1999. The Battle for Kursk, 1943: The Soviet General Staff Study. London and New York: Routledge.

Han, Sanggu. 1988. "Interviews of the Korean War (6.25 jeon-jaeng bal-bal-ui sil-snag-eul balg-hi-da)." Yeogsabipyeong. Critical Review of History. (September), 362-389.

Higgins, Marguerite. 1951. War in Korea: The Report of a Woman Combat Correspondent. New York, NY: Doubleday.

Jang, Jin Sung. 2013. Testimony (May 2). Accessed at http://www.chogabje. com/board/view.asp?C_IDX=51107\&C_CC=BJ (January 30, 2019).

Jang, Jun-ik. 1991. Puk'an Inmin Gundaesa (History on Korean People's Army). Seoul: Seomoondang. 
Ju, Young Bok. 1990. Naega Kyokkun Chosonjonjaeng 1 (My Experience for the Korean War 1). Seoul: Koryowon.

Kim, Donggil. 2011. "Stalin's Korea U-Turn: The USSR's Evolving Security Strategy and the Origins of the Korean War." Seoul Journal of Korean Studies 24(1), 89-114.

Kim, Donggil, and William Stueck. 2008. "Did Stalin Lure the United States into the Korean War? New Evidence on the Origins of the Korean War." North Korean International Documentation Project E-Dossier \#1.

Kim, Youngjun. 2017. Origins of the North Korean Garrison State: People's Army and the Korean War. London and New York: Routledge.

Kissinger, Henry. 1994. Diplomacy. New York, NY: Simon \& Schuster.

Kokoshin, Andre A. 1995. Soviet Strategic Thought, 1917-1991. London: MIT Press.

Lewis, Adrian R. 2017. The American Culture of War: The History of U.S. Military History from the Second World War to Operation Enduring Freedom. New York, NY: Routledge.

Millett, Allan R. 2010. The War For Korea, 1945-1950: A House Burning; A War For Korea, 1950-1951: They Came from North. Lawrence, KS: University Press of Kansas.

Odom, William E. 1998. The Collapse of the Soviet Military. London: Yale University Press.

Reynolds, David. 2006. From World War to Cold War: Churchill, Roosevelt, and the International History of the 1940s. Oxford, UK: Oxford University Press.

Roberts, Geoffrey. 2006. Stalin's Wars: From World War to Cold War, 19391953. London: Yale University Press.

Rozas, Danny, and Katheryn Weathersby. 1995. Cold War International History Project Bulletin Vol. 6-7.

Russian State Archive of Socio-Political History (RGASPI), Filipov (Stalin) Letter to Soviet Ambassador in Prague, conveying message to CSSR leader Klemont Gottwald, 27 August, 1950. http://digitalarchive. wilsoncenter.org/document/112225. "Letter from Filipov (Stalin) to Soviet Ambassador in Prague, conveying message to CSSR leader Klement Gottwald," August 27, 1950, History and Public Policy Program Digital Archive, Russian State Archive of Socio-Political History (RGASPI), fond 558, opis 11, delo 62, listy 71-72, reprinted in Andrei Ledovskii, "Stalin, Mao Tsedunh I Koreiskaia Voina 1950-1953 godov.” Novaia I Noveishaia Istoriia no. 5 (September-October 2005), 79-113. Translated by Gary Goldberg. 
Salisbury, Harrison E. 1969. War Between Russia and China. New York, NY: W. W. Norton \& Company.

Shechter, Jerrold L., and Vyacheslav V. Luchkov eds. 1990. Khrushchev Remembers: The Glasnost Tape. Boston: Little, Brown.

Shen, Zhihua. 2000. "Sino-Soviet Relations and the Origins of the Korean War: Stalin's Strategic Goals in the Far East." Journal of Cold War Studies 2(2), 44-68.

. 2010. "China and the Dispatch of the Soviet Air Force: The Formation of the Chinese-Soviet-Korean Alliance in the Early Stage of the Korean War." Journal of Strategic Studies 33(2), 211-230.

. 2012. "China and the Dispatch of the Soviet Air Force: The Formation of the Chinese-Soviet-Korean Alliance in the Early Stage of the Korean War." In Steven Casey ed., The Korean War at Sixty: New Approaches to the Study of the Korean War. New York, NY: Routledge, 49-69. 2013. Mao, Stalin and the Korean War: Trilateral Communist Relations in the 1950s. London and New York: Routledge.

Shen, Zhihua, and Danhui Li. 2011. After Leaning to One Side: China and Its Allies in the Cold War. Washington D.C.: Woodrow Wilson Center Press.

Shen, Zhihua, and Xia Yafeng. 2017. Mao and the Sino-Soviet Partnership, 1945-1959: A New History. New York, NY: Lexington Books.

Stone, David R. ed. 2010. The Soviet Union at War, 1941-1945. New York, NY: Pen \& Sword Books.

Stueck, William. 2002. Rethinking the Korean War: A New Diplomatic and Strategic History. Princeton, NJ: Princeton University Press.

Talbott, Strobe ed. 1971. Khrushchev Remembers. London: Andre Deutsch.

Thornton, Richard C. 2000. Odd Man Out: Truman, Stalin, Mao, and the Origins of the Korean War. Washington, D.C.: Potomac Books.

Van Ree, Erik. 1989. Socialism in One Zone: Stalin's Policy in Korea, 19451947. New York, NY: St. Martin's Press.

Walker, Jonathan. 2013. Operation Unthinkable: The Third World War. New York: The History Press.

Weathersby, Katheryn. 1993. "Soviet Aims in Korea and the Origins of the Korean War, 1945-1960: New Evidence from Russian Archives.” Cold War International History Project Working Paper No. 8.

. 1995a. "New Evidence on the Korean War." Cold War International History Project Bulletin 6/7, 30-125.

. 1995b. "To Attack or Not Attack? Stalin, Kim Il Sung, and Prelude to War." Cold War International History Project Bulletin Vol. 5. 
. 2002. "Should We Fear This? Stalin and the Danger of War with American." Cold War International History Project Working Paper No. 39 . . 2003. "New Evidence on North Korea." Cold War International History Project Bulletin 14/15, 5-138.

Weathersby, Katheryn, and Gyu-hyong Kang. 2010. "Puk-Chung-So Samgakkwan'gyega 6.25 Chonjaeng Kwajonggwa Chonhu Puk'anoegyo Haengt'aee Mich'in Yonghyang: Kimirhaejemunsorul Chungshimuro (Influence of Triangle Relations among North Korea, China and the Soviet Union and the Korean War on North Korean Foreign Policy: Based on Declassified Documents." Chongshin Munhwa Yon'gu (Studies on Spiritual Culture) 33(3), 117-142.

Tukhachevsky, Mikhail N. 1921. Voina Klassov (War of the Classes). Moscow: Gosizdat. . 1927. "K voprosu o sovremennoi strategii (On the Question of Modern Strategy)." In Voina i voennoe iskusstvo $v$ svete istoricheskogo materializma (War and the art of war in light of historical materialism). Moscow: Gosizdat. . 1930. "O kharaktere sovremennykh voin v svete reshenii VI Kongressa Kominterna." (On the Character of Modern Wars in Light of the Decisions of the Sixth Commintern Congress), in Zapiski Kommunisticheskoi Akademii (Proceedings of the Communist Academy). Moscow: Komakademiya.

Yu, Song Chol. 1990. "My Testimony." Hankook Ilbo (November 9 and 13).

Zubok, Vladislav M. 2007. A Failed Empire: The Soviet Union in the Cold War from Stalin to Gorbachev. Chapel Hill, NC: The University of North Carolina Press. 